\title{
RATING FORCES GRIP AND DRIVING AND ACCELERATIONS OF THE CAR WITH DRIVE DIFFERENT CONFIGURATION
}

\section{OCENA SIL PRZYCZEPNOŚCI I NAPĘDOWYCH ORAZ PRZYSPIESZEŃ SAMOCHODU OSOBOWEGO Z RÓŻNĄ KONFIGURACJĄ NAPĘDU}

\author{
Mariusz Kowalski \\ 1 Baza Lotnictwa Transportowego \\ e-mail:mkowalski1102@gmail.com
}

\begin{abstract}
The paper shows a typical drive systems used in today's vehicles, mainly cars. Approximated scheme of the formation of the driving force of the vehicle and the necessary mathematical relations for the calculation. For example, a typical passenger car BMW 320 was analyzed and calculations obtained a driving force, of adhesion and acceleration. The calculations were performed for the drive system, the classical (i.e. the rear axle of the vehicle) for front-wheel drive and four-wheel drive (4x4). Virtually assumed that to the above mentioned vehicle it is possible buildings of each of said system. These are shown graphically in diagrams bearing a distribution of the forces acting on the substrate and the reactions - the data necessary for the calculations. The resulting calculation is graphically shown in the diagrams, in which is illustrated a change value of the resulting adhesive strength, and the acceleration depending on the drive type vehicle.
\end{abstract}

Keywords: drive systems cars, siła przyczepności pojazdu, siła napędowa

Streszczenie: $W$ referacie przedstawiono typowe uktady napędowe stosowane we wspótczesnych samochodach, gtównie osobowych. Przybliżono schemat powstawania sity napędowej pojazdu oraz niezbędne zależności matematyczne do jej obliczenia. Na przykładzie typowego samochodu osobowego typu BMW 320 przeprowadzono analize oraz obliczenia uzyskiwanej sity napędowej, sit przyczepności oraz przyspieszenia. Obliczenia przeprowadzono dla uktadu napędowego, klasycznego ( $t j$. na tylnq oś pojazdu), dla napędu na przedniq oś oraz napędu na obie osie (4x4). Przyjęto wirtualnie, że na wyżej wymienionym samochodzie jest możliwa zabudowa każdego z wymienionych układów. Przedstawiono je graficznie na schematach, na których zamieszczono rozklad sit dziatajacych na podtoże i reakcje - dane niezbędne do przeprowadzenia obliczeń. Uzyskane obliczenia przedstawiono graficznie na wykresach, na których zobrazowano zmiane wartości uzyskiwanej sity przyczepności oraz przyspieszenia $w$ zależności od typu napędu samochodu.

Slowa kluczowe: uktady napędowe samochodów, siła przyczepności pojazdu, siła napędowa 
Rating forces grip and driving and accelerations of the car with drive different... Ocena sit przyczepności i napędowych oraz przyspieszeń samochodu osobowego...

\section{Wprowadzenie}

Ruch każdego pojazdu mechanicznego jest możliwy dzięki istnieniu tzw. sile napędowej wytwarzanej przez silnik i przenoszonej następnie na koła jezdne w sposób kontrolowany przez kierowcę i zapewniający optymalne jej wykorzystanie w różnych warunkach ruchu.

Rozróżnia się układy napędowe mechaniczne (najczęściej stosowane w samochodach, motocyklach), hydrostatyczne i elektryczne. Typowy układ napędowy samochodu składa się ze sprzęgła, skrzyni biegów, wału napędowego i mostu napędowego. Przenoszenie siły napędowej następuje poprzez układ napędowy, którego konstrukcja wynika przede wszystkim z rozmieszczenia poszczególnych jego elementów. $Z$ tego powodu rozróżnia się:

- układ klasyczny, w którym silnik jest zabudowany wzdłużnie z przodu samochodu i napędza tylną jego oś - rys. 1.

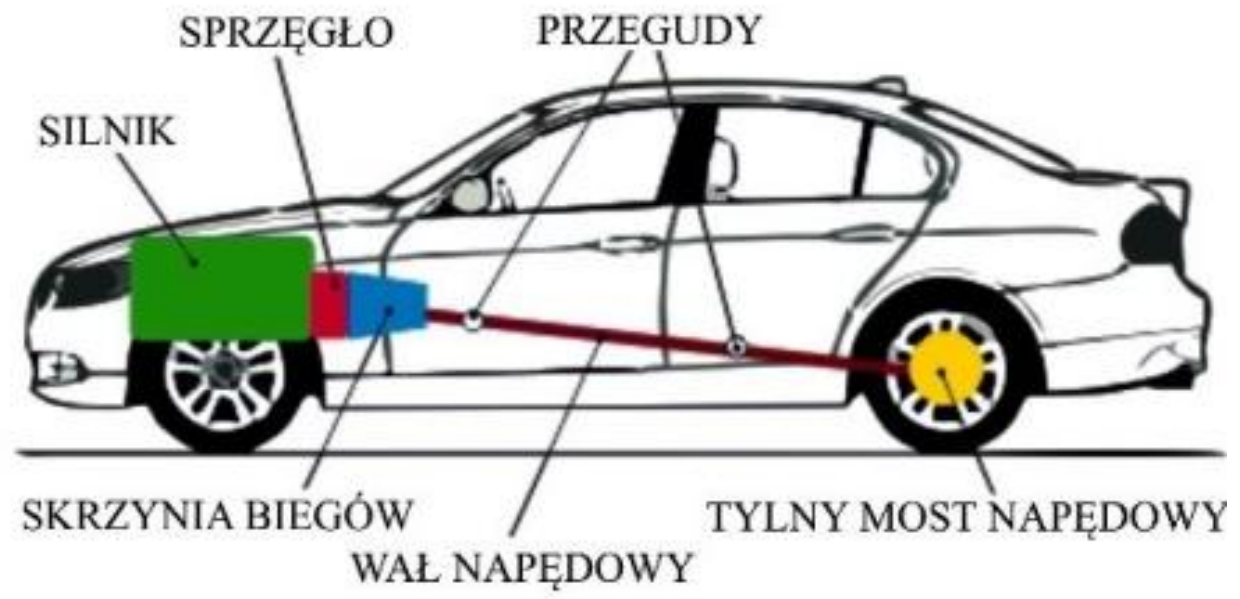

Rys. 1 Schemat klasycznego uktadu napędowego samochodu

W tym układzie silnik wraz ze sprzęgłem i skrzynią biegów jest zabudowany z przodu samochodu. Napęd przekazywany jest poprzez wał napędowy do tylnego mostu i na koła napędzane samochodu. W samochodach osobowych tego rodzaju układ napędowy jest rzadziej stosowany $\mathrm{z}$ uwagi na trudności konstrukcyjne i zwiększone koszty produkcji. Nie mniej jednak istnieje kilka firm preferujących tego rodzaju układ napędowy jak np. firma BMW, czy Mercedes. 
- układ przedni zblokowany (zespolony), w którym silnik jest zabudowany z przodu samochodu i napędza przednią jego oś - rys. 2.

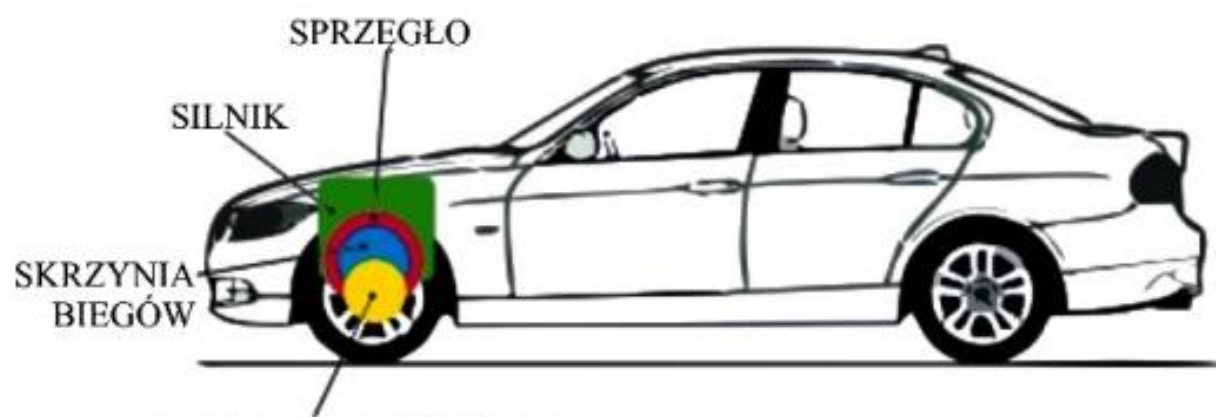

PRZEKŁADNIA GLÓWNA I MECHANIZM RÓŻNICOWY

Rys. 2 Schemat uktadu napędowego przedniego zblokowanego

W tym układzie główne elementy - silnik, sprzęgło, skrzynia biegów, przekładnia główna i mechanizm różnicowy - stanowią zwartą konstrukcję umieszczoną na przodzie samochodu. Silnik najczęściej umieszczony jest poprzecznie do osi podłużnej samochodu. Układ ten jest bardzo popularny w układach napędowych samochodów osobowych miejskich, kompaktowych oraz klasy średniej.

- układ tylny zespolony, w którym silnik jest zabudowany z tyłu samochodu i napędza tylną jego oś - rys. 3.

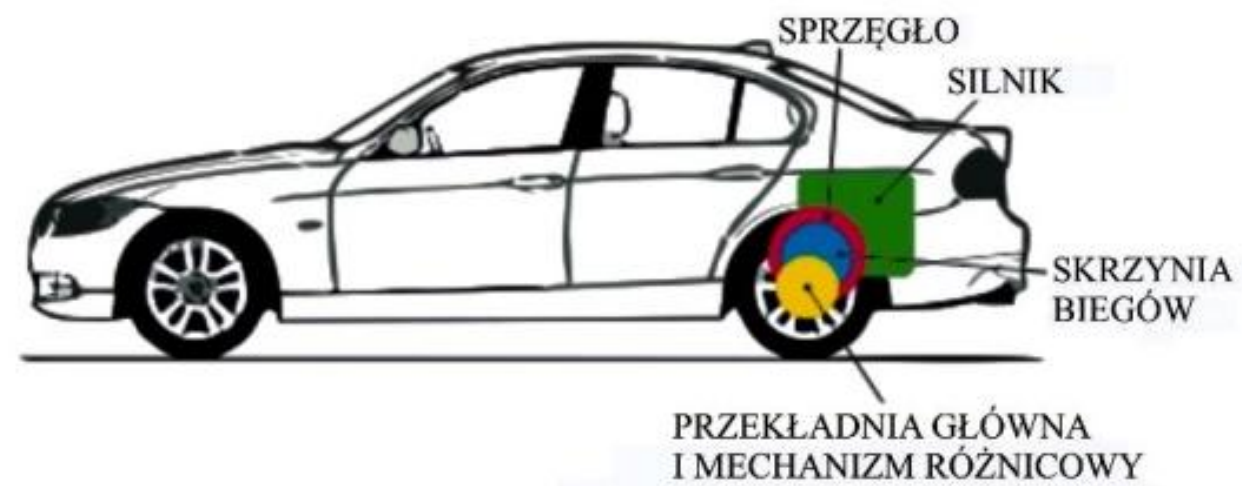

Rys. 3 Schemat uktadu napędowego tylny zespolony

W tym układzie silnik zabudowany jest $\mathrm{z}$ tyłu i jest zblokowany ze skrzynią biegów, przekładnią główną i mechanizmem różnicowym. Aktualnie układ ten praktycznie nie jest stosowany z uwagi na niekorzystny wpływ na kierowalność samochodu w trudnych warunkach atmosferycznych np. zimą. Typowym przykładem samochodu, w którym zastosowano tego rodzaju układ napędowy jest Fiat 126p. 
Rating forces grip and driving and accelerations of the car with drive different... Ocena sit przyczepności i napędowych oraz przyspieszeń samochodu osobowego...

- uklad centralny, w którym silnik umieszczony jest z tyłu pojazdu, ale przed tylna osią i napędza tylną jego oś - rys. 4.

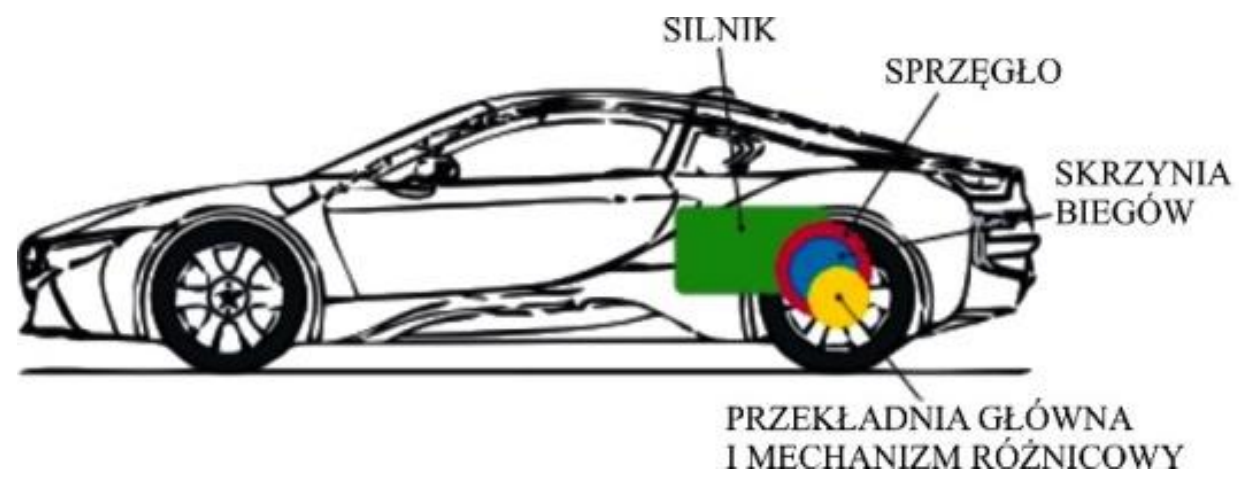

Rys. 4 Schemat ukladu napędowego centralnego

Układ ten jest stosowany tylko w samochodach sportowych. Silnik jest zabudowany przed tylną osią, co dość istotnie ogranicza miejsce w kabinie, stąd też są to zwykle samochody dwumiejscowe. Centralnie zabudowanie silnika i jego zespołów daje lepsze obciążenie na obie osie i korzystnie wpływa na położenie środka masy.

- układ 4x4, w którym silnik jest zabudowany wzdłużnie z przodu samochodu i napędza obie jego osie - rys. 5 .

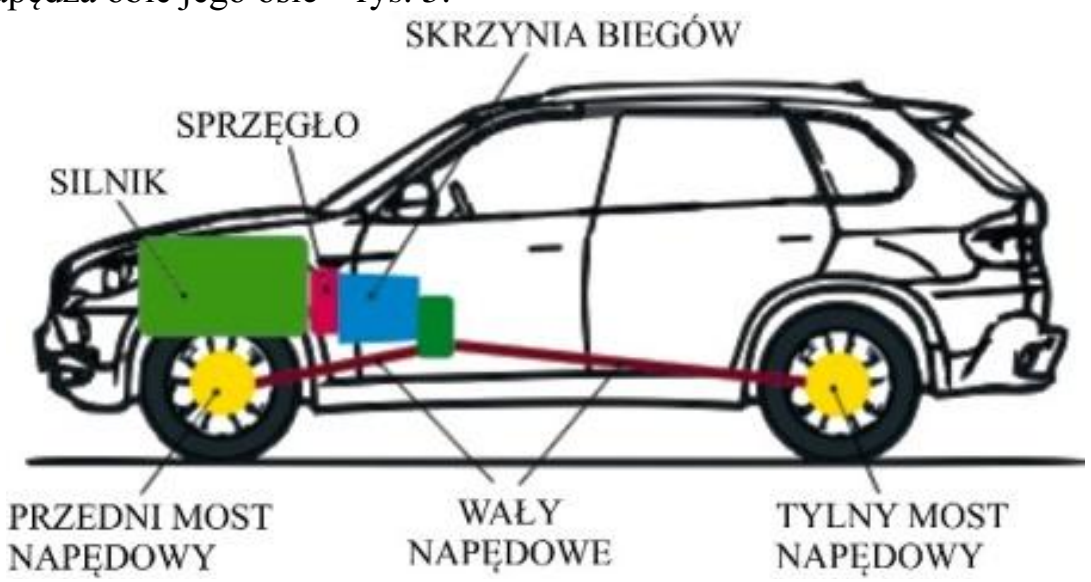

Rys. 5 Schemat uktadu napędowego $4 \times 4$

Układ ten stosowany jest głównie w samochodach sportowych i terenowych. Posiada bardzo dobre własności ruchowe, ale zajmuje najwięcej miejsca i jest najbardziej skomplikowany oraz kosztowny. Występuje on w dwóch typach, tj. ze stałym napędem na obie osie - niekoniecznie w proporcji po $50 \%$ mocy oraz w napędzie dołączanym np. przednia oś jest dołączana w sposób automatyczny lub ręczny w zależności od warunków drogowych i decyzji kierowcy. 


\section{Sila napędowa - teoria}

Jak wspomniano powyżej ruch samochodu jest wynikiem przekazywania napędu z silnika poprzez układ napędowy na koła napędowe. Przekazywany moment obrotowy na koła napędzające powoduje powstawanie sił obwodowych toczących się kół (rys. 6).

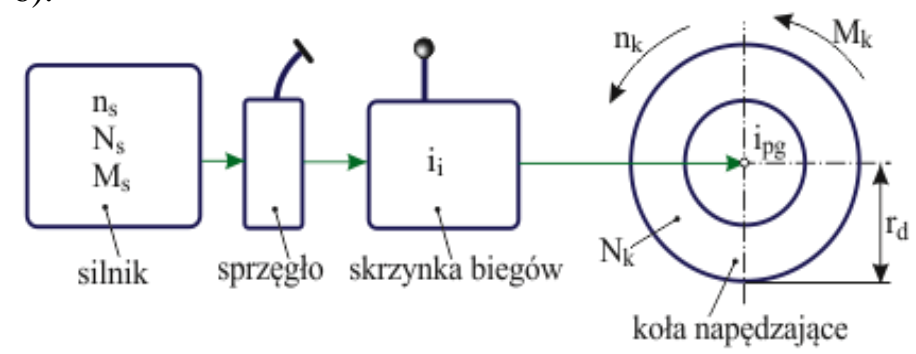

Rys. 6 Schemat ukladu napędowego - sity obwodowe napędzajace koła napędowe [10]: $n_{s}$ - prędkośc obrotowa silnika [obr/min]; $N_{s}-$ moc silnika [kW]; $M_{s}-$ moment obrotowy silnika [Nm]; $i_{i}$ - przetożenie skrzynki biegów; $r_{d}$ - promień dynamiczny koła $[\mathrm{m}] ; i_{p g}$ - przełożenie przekładni gtównej; $n_{k}$ - prędkość obrotowa kót napędzajacych [obr/min]; $N_{k}-$ moc przenoszona na koła napędowe [kW];

$$
M_{k} \text { - moment obrotowy przenoszony na kota [Nm] }
$$

Suma tych sił stanowi siłę napędową, która wprawia $\mathrm{w}$ ruch postępowy samochodów. Ruch ten jest wynikiem istnienia siły przyczepności przeciwdziałającej ślizganiu się kół. Wartość uzyskiwanej siły napędowej zależy od wielkości przekazywanego z silnika momentu obrotowego, przełożeń skrzynki napędów i przekładni głównej oraz sprawności mechanicznej całego układu.

Zmiana siły napędowej jest wynikiem zmiany momentu obrotowego, co możemy zauważyć poprzez obserwację charakterystyki zewnętrznej silnika (rys. 7).

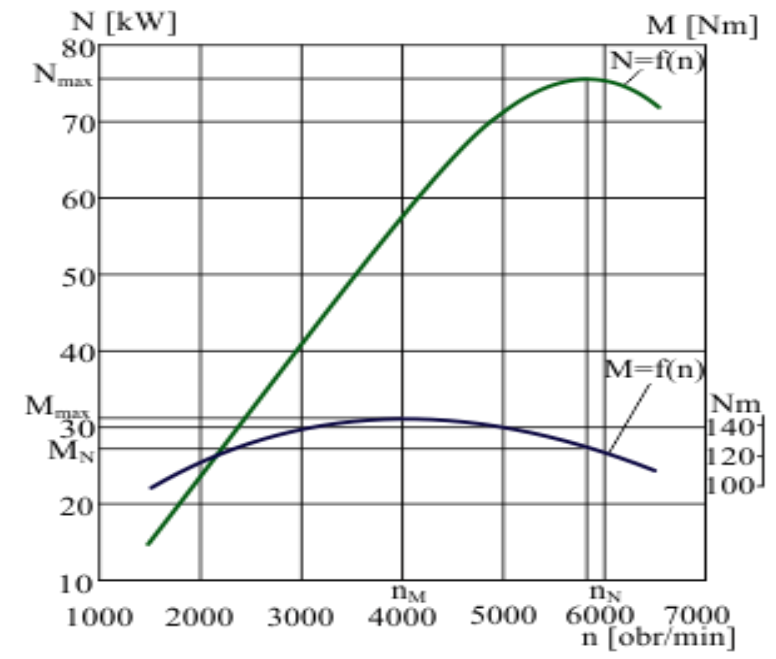

Rys. 7 Przyklad charakterystyki zewnętrznej silnika

z jej charakterystycznymi punktami [10] 
Rating forces grip and driving and accelerations of the car with drive different... Ocena sit przyczepności i napędowych oraz przyspieszeń samochodu osobowego...

Charakterystyka zewnętrzna silnika przedstawia zależność mocy $N$ i momentu obrotowego $M \mathrm{w}$ funkcji prędkości obrotowej $\mathrm{n}$, w czasie, gdy silnik pracuje $\mathrm{z}$ całkowicie otwartą przepustnicą lub $\mathrm{z}$ pompą ustawioną na maksymalny wydatek. Pozwala ona na określenie maksymalnej prędkości z jaką może jechać samochód przy określonych oporach ruchu.

Uzyskiwaną wartość siły napędowej $F_{N}$ można obliczyć z zależności (1), z której wynika, że jest ona określona ilorazem momentu obrotowego na kole napędzającym $M_{k}$ i promienia dynamicznego $r_{d}$.

$$
F_{N}=\frac{M_{k}}{r_{d}}
$$

Moment obrotowy przenoszony przez koła, po uwzględnieniu przełożenia i sprawności układu napędowego można wyznaczyć z zależności:

$$
M_{k}=M_{s} \cdot i_{U N} \cdot \eta_{U N}
$$

gdzie: $M_{s} \quad$ - moment obrotowy silnika,

$i_{U N} \quad$ - całkowite przełożenie układu napędowego,

$\eta_{U N} \quad$ - sprawność układu napędowego (zwykle wynosi od $0.85 \div 0.95$ ).

Stąd wartość siły napędowej $\mathrm{F}_{\mathrm{N}}$ można wyznaczyć z zależności:

$$
F_{N}=\frac{M_{s} \cdot i_{U N} \cdot \eta_{U N}}{r_{d}}
$$

Całkowite przełożenie układu napędowego można obliczyć z zależności:

$$
i_{U N}=i_{i} \cdot i_{p g}
$$

gdzie: $i_{i} \quad$ - przełożenie na i-tym biegu;

$i_{p g} \quad$ - przełożenie przekładni głównej.

Natomiast sprawność układu napędowego przy połączeniu szeregowym poszczególnych elementów tego układu można obliczyć z zależności:

$$
\eta_{U N}=\eta_{1} \cdot \eta_{2} \cdot \ldots \cdot \eta_{n}=\prod_{i=1}^{n} \eta_{i}
$$

Promień dynamiczny koła można obliczyć w przybliżony sposób z zależności [9]:

$$
r_{d}=0.97 \cdot\left(H+r_{f}\right)
$$

gdzie: $H$ - wysokość opony, którą można wyznaczyć jako iloczyn szerokości opony i jej profilu;

$r_{f} \quad$ - promień obręczy koła. 
Znając wartość siły napędowej można obliczyć przyspieszenie samochodu wykorzystując zależność:

$$
a_{s}=\frac{d v}{d t}=\frac{F_{B} \cdot g}{\delta \cdot Q}
$$

gdzie: $F_{B}$-siła bezwładności, w przybliżeniu równa co do wartości sile napędowej, ale skierowana przeciwnie do niej w $[\mathrm{N}]$;

$g$ - przyspieszenie ziemskie;

$Q$ - ciężar całkowity samochodu w $[\mathrm{N}]$;

$\delta$ - współczynnik mas wirujących, dla samochodów osobowych wyliczany z zależności:

$$
\delta=1+0.03 \cdot i_{s b}^{2}
$$

gdzie: $i_{s b}$ - przełożenie skrzyni biegów na danym biegu.

\section{Obliczenia i wyniki}

Obliczenia przeprowadzono wykorzystując dane pozyskane $\mathrm{Z}$ samochodu osobowego typu BMW 320, przyjmując założenie (hipotetyczne), że może on mieć różną konfigurację układu napędowego (tylko na przednią oś, tylko na tylną oś i na obie osie). Jego podstawowe dane niezbędne do obliczeń to: masa całkowita $m_{c}=1570[\mathrm{~kg}]$, na którą składa się masa własna samochodu wynosząca $1430[\mathrm{~kg}]$ plus masa paliwa $60[\mathrm{~kg}]$ plus masa kierowcy $80[\mathrm{~kg}]$. Podstawowe wymiary tego pojazdu przedstawiono na rys. 8 .

Sprawność układu napędowego z napędem na tylną oś (układ szeregowy), można obliczyć z zależności:

$$
\eta_{U N}=\eta_{s p} \cdot \eta_{s b} \cdot \eta_{w} \cdot \eta_{p g} \cdot \eta_{d d}
$$

gdzie: $\eta_{s p}-$ sprawność sprzęgła $\left(\eta_{s p}=1\right)$;

$\eta_{s b}$ - sprawność skrzynki biegów $\left(\eta_{s b}=0.98\right)$;

$\eta_{w}$ - sprawność wału napędowego $\left(\eta_{w}=0.99\right)$;

$\eta_{p g}$ - sprawność przekładni głównej $\left(\eta_{p g}=0.96\right)$;

$\eta_{d d}$ - sprawność dodatkowych zespołów układu napędowego $\left(\eta_{d d}=0.97\right)$.

Dla napędu na tylną i przednią oś, sprawność układu napędowego, po uwzględnieniu danych z zależności (7) wynosi: $\eta_{U N}=0.90$ (na I i II biegu). Dla napędu na obie osie $(4 \times 4) \eta_{U N}=0.88$.

Promień dynamiczny koła samochodu BMW 320 (rozmiar ogumienia $225 \times 55 \times 16$ ) wynosi:

$$
r_{d}=0.97 \cdot\left(H+r_{f}\right) \approx 0.327 m
$$


Rating forces grip and driving and accelerations of the car with drive different... Ocena sit przyczepności i napędowych oraz przyspieszeń samochodu osobowego...
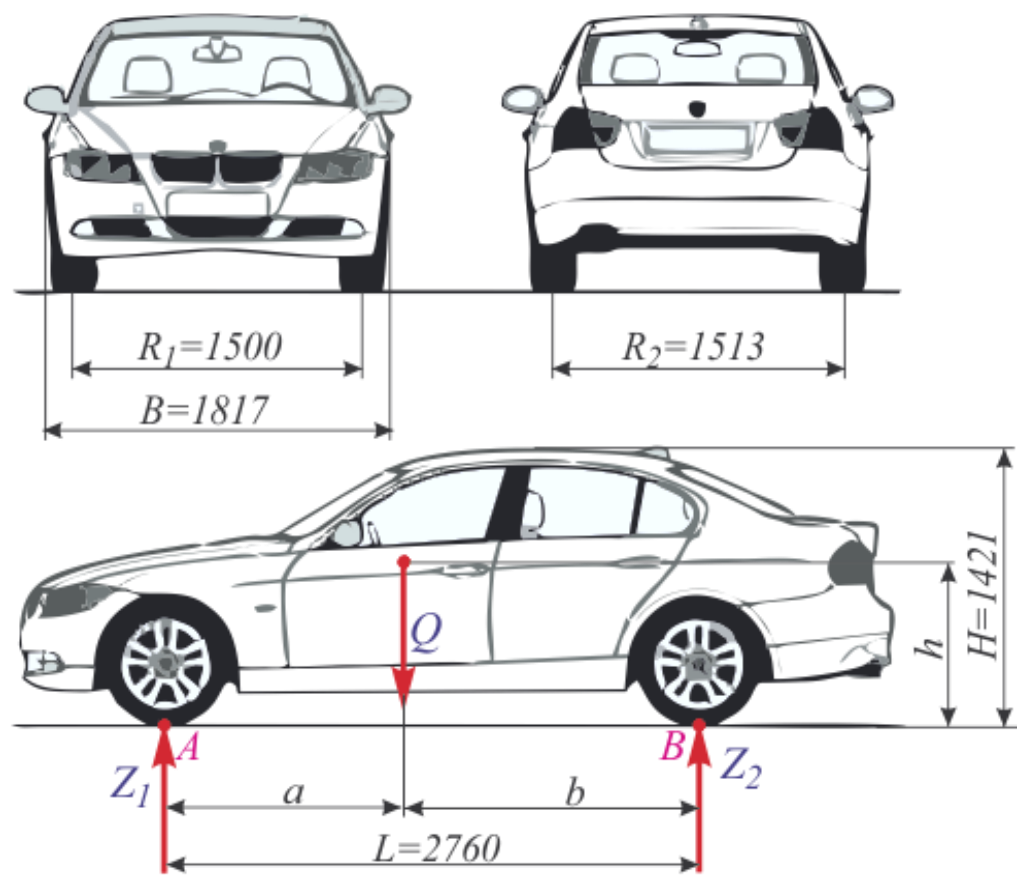

Rys. 8 Wymiary i obciązenia statyczne dziatajace na samochód BMW 320 podczas postoju na jezdni poziomej: $Q$ - ciężar samochodu $\left(Q=m_{c} \cdot g\right)$;

$Z_{1}, Z_{2}$ - sity reakcji podtoża; $L$ - rozstaw osi kół; $a, b, h$-wspótrzędne środka masy samochodu

\section{Sity reakcji podtoża}

Na każdy samochodów - niezależnie od jego ruchu - działają tzw. obciążenia statyczne, które są wynikiem działania ciężaru samochodu na podłoże. Siła ciężkości (skierowana do podłoża), wywołuje reakcje $Z_{1}$ i $Z_{2}$ - rys. 8 .

Uwzględniając procentowy stosunek obciążenia samochodu BMW 320, który wynosi: na przednią oś $52.2 \%$ i na tylną oś $47.8 \%$, wartości poszczególnych reakcji wynoszą:

$$
Z_{1} \approx 8040[N] ; Z_{2} \approx 7362[N] \text { i obciażenie calkowite } Q \approx 15402[N]
$$

Natomiast po przekształceniach równania równowagi sił momentów (rys. 9) wyznaczono wartości $a$ i $b$ określające położenie środka masy samochodu:

$$
a=1.32 \mathrm{~m} ; b=1.44 \mathrm{~m}
$$

Zaś wysokość h wynosi:

$$
h=0.38 \cdot 1421 \mathrm{~mm}=540 \mathrm{~mm}=0.54 \mathrm{~m}
$$




\section{Sily przyczepności - samochód z napedem na tylna oś}

Do obliczeń - dla samochodu BMW 320 - przyjęto: moment obrotowy silnika $M_{s}=350 \mathrm{Nm}$, przełożenie na I biegu $i_{s b 1}=3.25$, na II biegu $i_{s b 1}=2.10$, przełożenie przekładni głównej $i_{p g}=4.45$. Podczas ruchu rozkład sił (przy pominięciu sił oporu toczenia i powietrza) jest jak na rys. 9.

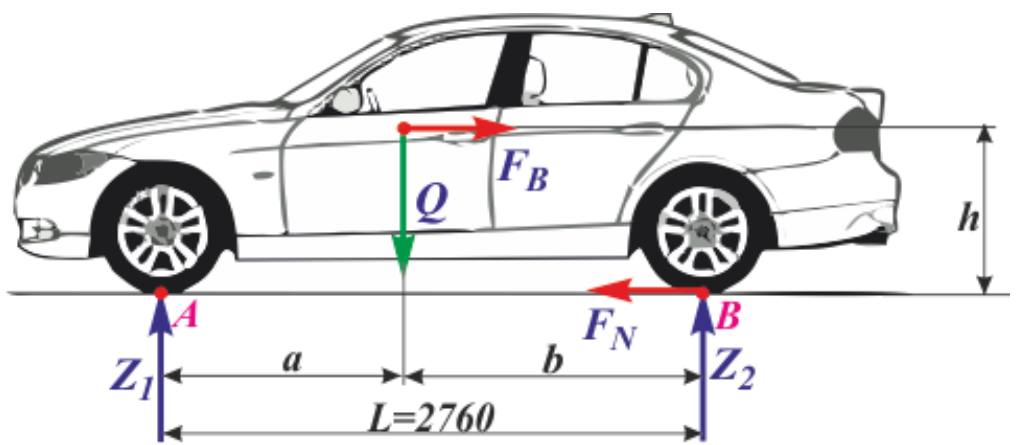

Rys. 9 Rozkład sił działających na samochód z napędem na tylna oś w ruchu

Przełożenie układu napędowego wynosi:

- na I biegu: $i_{U N}=i_{1} \cdot i_{p g}=3.25 \cdot 4.45=14.46$;

- na II biegu: $i_{U N}=i_{2} \cdot i_{p g}=2.10 \cdot 4.45=9.345$.

Z zależności (3) i po podstawieniu odpowiednich danych, siła napędowa maksymalna od silnika - wynosi: na I biegu $F_{N 1}=13929[N]$, na II biegu $F_{N 2}=9002[N]$.

Przeprowadzając obliczenia dla jezdni suchej (współczynnik tarcia $\mu=0.75$ ) oraz dla jezdni mokrej (współczynnik tarcia $\mu=0.48$ ), uzyskano wartości sił przyczepności dla samochodu typu BMW 320 z napędem na tylną oś - patrz rys. 10.

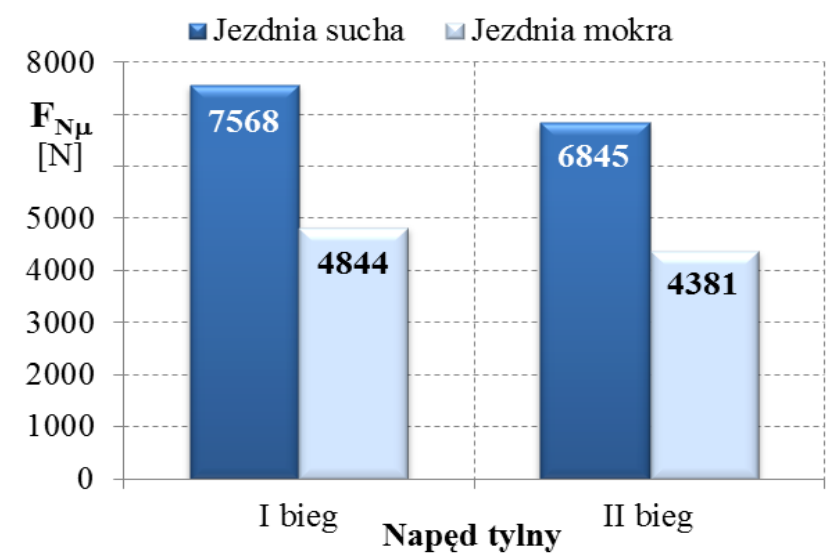

Rys. 10 Zmiana sity przyczepności na I i II biegu na jezdni suchej i mokrej 
Rating forces grip and driving and accelerations of the car with drive different... Ocena sit przyczepności i napędowych oraz przyspieszeń samochodu osobowego...

Stwierdzono, że wartość siły przyczepności na II biegu jest nieco niższa niż na I biegu zarówno na jezdni suchej jak i mokrej. Wartość spadku uzyskiwanych sił przyczepności na jezdni mokrej jest dość znaczny - sięga 36\%.

\section{Sily przyczepności - samochód z napędem na przednią oś}

Dane wejściowe do obliczeń - dla samochodu BMW 320 - z napędem na przednią oś przyjęto podobnie jak dla napędu na tylną oś. Podczas ruchu rozkład sił (przy pominięciu sił oporu toczenia i powietrza) jest jak na rys. 11 .

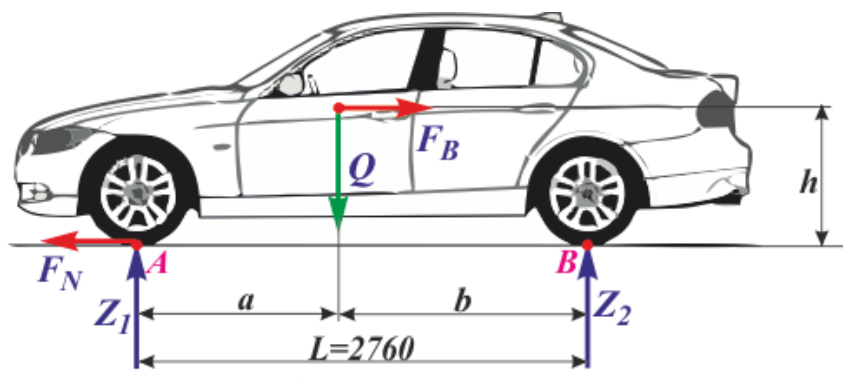

Rys. 11 Rozktad sił działających na amochód z napędem na przednia oś w ruchu

Wartości sił napędowych (maksymalne od silnika) są podobne jak dla samochodu z napędem na tylną oś i wynoszą: na I biegu $F_{N 1}=13929$ [N], na II biegu $F_{N 2}=9002[N]$.

Obliczenia również przeprowadzano dla jezdni suchej, gdzie współczynnik tarcia $\mu=0.75$ oraz dla jezdni mokrej, gdzie współczynnik tarcia $\mu=0.48$.

Zmianę uzyskiwanych wartości sił przyczepności dla samochodu typu BMW 320 $\mathrm{z}$ napędem na przednią oś przedstawiono na 0 .

Dla samochodu z napędem przednim, wartość siły przyczepności na II biegu jest wyższa niż na I biegu zarówno na jezdni suchej jak i mokrej. Wartość spadku uzyskiwanych sił przyczepności na jezdni mokrej jest dość znaczny - sięga 44\%.

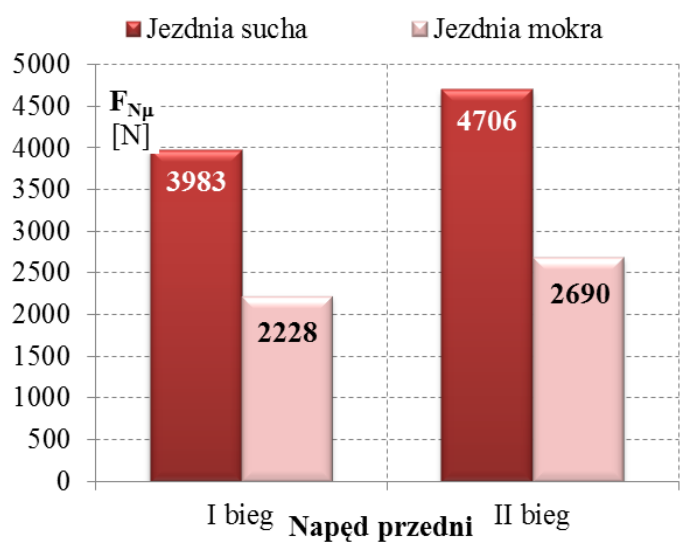

Rys. 12 Zmiana siły przyczepności na I i II biegu na jezdni suchej i mokrej 
Siły przyczepności - samochód z napędem na obie osie $(4 \times 4)$

Dane wejściowe do obliczeń - dla samochodu BMW 320 - z napędem na obie osie $4 \mathrm{x} 4$ przyjęto podobnie jak wyżej. Podczas ruchu rozkład sił (przy pominięciu sił oporu toczenia i powietrza) jest jak na rys. 13.

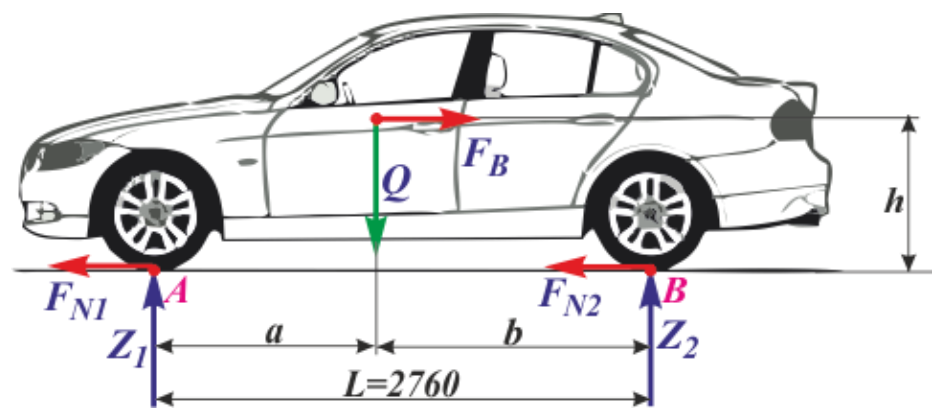

Rys. 13 Rozkład sił działających na samochód z napędem na obie osie (4x4)

Wartości sił napędowych (maksymalne od silnika) wynoszą: na I biegu $F_{N 1}=13234[N]$, na II biegu $F_{N 2}=9199[N]$.

Obliczenia również przeprowadzano dla jezdni suchej, gdzie współczynnik tarcia $\mu=0.75$ oraz dla jezdni mokrej, gdzie współczynnik tarcia $\mu=0.48$.

Zmianę uzyskiwanych wartości sił przyczepności dla samochodu typu BMW 320 $\mathrm{z}$ napędem na obie osie przedstawiono na rys. 14 .

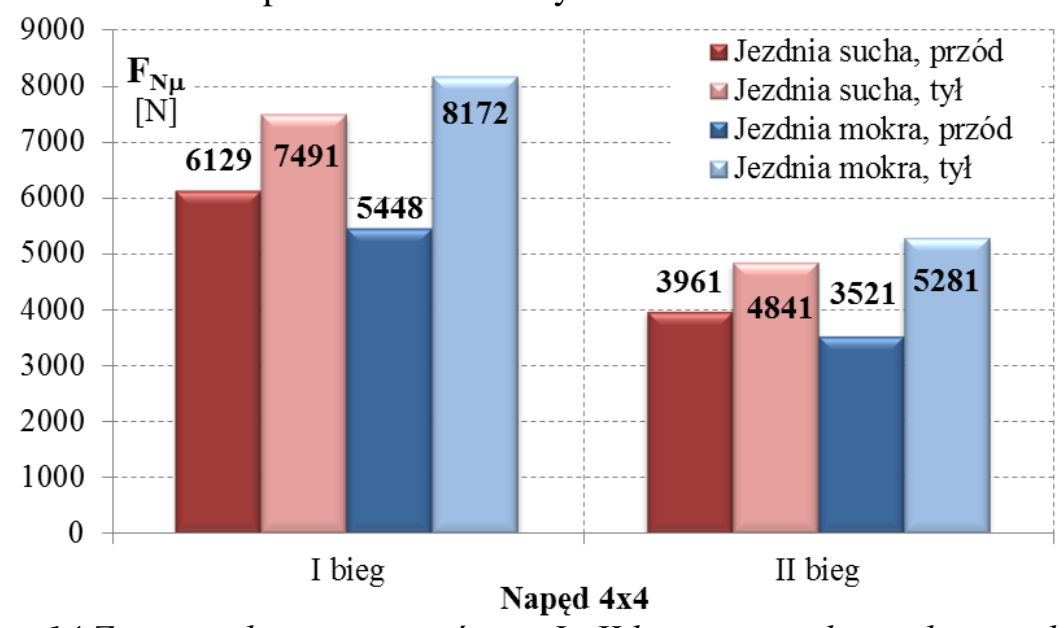

Rys. 14 Zmiana sity przyczepności na I i II biegu na jezdni suchej i mokrej dla osi przedniej i tylnej

Dla samochodu $\mathrm{z}$ napędem na obie osie $(4 \mathrm{x} 4)$, wartości sił przyczepności na I biegu są wyższa niż na II biegu zarówno na jezdni suchej jak i mokrej. Wartość spadku uzyskiwanych sił przyczepności na jezdni mokrej jest dość znaczny - sięga 35\%. 
Rating forces grip and driving and accelerations of the car with drive different... Ocena sit przyczepności i napędowych oraz przyspieszeń samochodu osobowego...

\section{Przyspieszenia samochodu dla różnej konfiguracji napędu}

Po uwzględnieniu wyżej obliczonych wartości sił przyczepności oraz sił napędowych przeprowadzono analizę możliwych do uzyskania przyspieszeń samochodu. Stwierdzono, że w wyniku zastosowania różnej konfiguracji napędu dla samochodu BMW 320, można uzyskać równe wartości przyspieszenia samochodu - rys. 15 i 16.

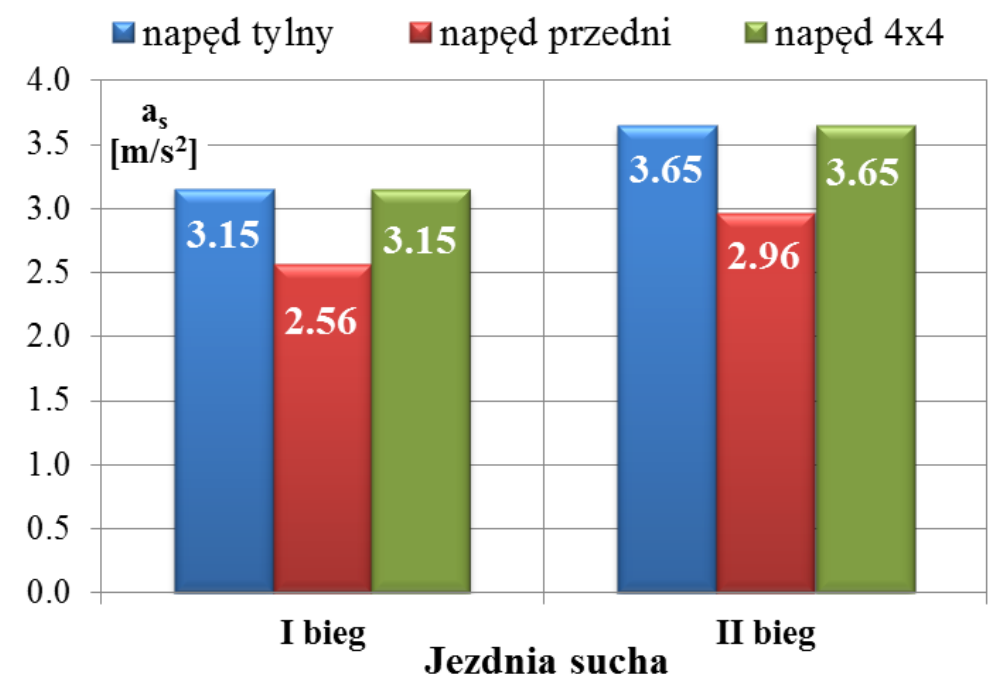

Rys. 15 Uzyskiwane wartości przyspieszenia samochodu BMW 320 do zrównania sił napedowych i przyczepności

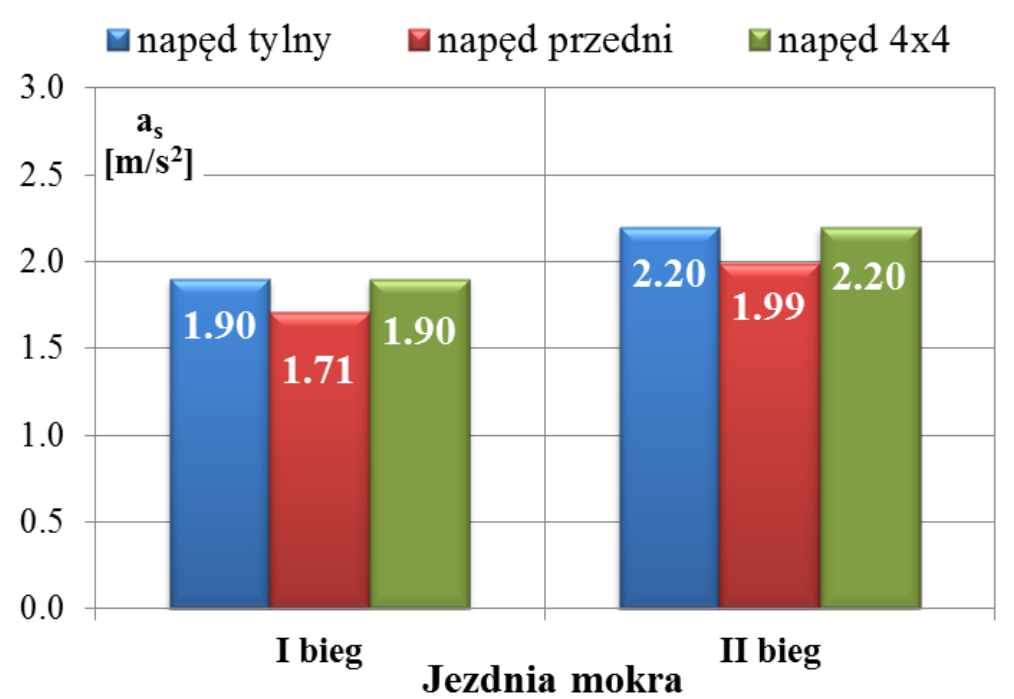

Rys. 16 Uzyskiwane wartości przyspieszenia samochodu BMW 320 do zrównania sił napedowych i przyczepności 
Stwierdzono, że jezdnia mokra powoduje dość znaczne obniżenie wartości siły przyczepności samochodu do drogi i praktyczne niezależnie od typu napędu sięga 40 i więcej procent. Ponadto uzyskiwane przyspieszenia dla napędu na tylną oś oraz dla napędu na obie osie są niemal identyczne, zarówno na jezdni suchej jak i mokrej dla tego typu samochodu osobowego. Jedynie analizowany samochód z napędem na przednią oś ma niższe wartości uzyskiwanych przyspieszeń od pozostałych o około $19 \%$.

\section{Wnioski końcowe}

$\mathrm{Z}$ analizy i przeprowadzonych obliczeń symulacyjnych wynika, że nie bez powodu w samochodach osobowych firmy BMW są stosowane tylko układy z napędem na tylną oś oraz napędy na obie osie w bogatszych modelach. Napęd na tylną oś pozwala na uzyskiwanie znacznie większych sił przyczepności oraz przyspieszeń. $\mathrm{Z}$ tego m.in. powodu tego typu napędy są stosowane praktycznie we wszystkich samochodach sportowych. Dodatkowo pamiętać należy, że napęd tylny (nazywany także klasycznym) to napęd wymagający znacznie więcej umiejętności od kierowcy, ale też jest bardziej komfortowy podczas jazdy. $Z$ tych względów, to właśnie napęd klasyczny jest wykorzystywany w bogatych wersjach samochodów klasy premium, gdzie tak naprawdę najbardziej liczy się prestiż i radość z jazdy. Należy jednak pamiętać, że nie stosowane układy napędowe na przednią oś w samochodach firmy BMW posiadają wiele innych zalet, które z punktu widzenia przeciętnego użytkownika są istotniejsze jak chociażby kwestia kontroli pojazdu w zakrętach przy małych i średnich prędkościach, dobra zdolność pokonywania wzniesień przy małych obciążeniach, mała wrażliwość na wiatr itp. Napęd przedni jest po prostu łatwiejszy w prowadzeniu dla kierowców z małym doświadczeniem

\section{Literatura}

[1] Dębiński M.: Teoria ruchu samochodu. Transport and Communication Publishers, Warsaw 1979.

[2] Fundowicz P., Radzimierski M., Wieczorek M.: Konstrukcja pojazdów samochodowych. Wyd. Szkolne i Pedagogiczne S.A. Warszawa 2010.

[3] Kowalski M.: Ocena stanu technicznego układów decydujących o bezpieczeństwie jazdy w samochodach o dopuszczalnej masie całkowitej do 3,5 t. Promoter Thesis: Dziubak T. Military University of Technology, Warsaw 2012.

[4] Kowalski M.: The effect of automotive vehicle braking system failure on driving safety. Journal of KONES Powertrain and Transport. Vol. 20, No. 1 Warsaw 2013. 
Rating forces grip and driving and accelerations of the car with drive different... Ocena sit przyczepności i napędowych oraz przyspieszeń samochodu osobowego...

[5] Kowalski M.: Safe speed of a passenger car in circular motion. Journal of KONES Powertrain and Transport. w druku, Warsaw 2014.

[6] Prochowski L.: Mechanika ruchu. Transport and Communication Publishers, Warsaw 2005.

[7] Siłka W.: Teoria ruchu samochodu. Science and Technology Publishers (WNT), Warsaw 2002.

[8] The BMW 320 user manual available at: http://www.inchcape.com.pl/repozytorium/userfiles/viewers/e90-instrukcja/index.html.

[9] Warczek J.: Metoda pomiaru promienia dynamicznego koła samochodowego. Zeszyty Naukowe Politechniki Śląskiej nr 67, Nr kol. 1832, 2010.

[10] http://autowiedza.republika.pl/sila_napedowa.html.

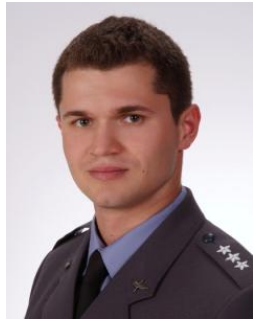

por. mgr inz. Mariusz Kowalski jest absolwentem Wojskowej Akademii Technicznej w Warszawie, która ukończyt w 2012 roku na Wydziale Mechanicznym. Pracuje w 1 Bazie Lotnictwa Transportowego w Warszawie na stanowisku Dowódcy Kompani Zabezpieczenia. Główne obszary jego działalności oraz zainteresowania to motoryzacja, jej rozwój, konstrukcje oraz eksploatacja i diagnostyka pojazdów mechanicznych oraz ich zespołów napędowych. 